Original research article

\title{
Simultaneous analysis of sugars and organic acids in wine and grape juices by HPLC: Method validation and characterization of products from northeast Brazil
}

\author{
Emanuela Monteiro Coelho ${ }^{\mathrm{a}}$, Carla Valéria da Silva Padilha ${ }^{\mathrm{a}}$, Gabriela Aquino Miskinis ${ }^{\mathrm{a}}$,

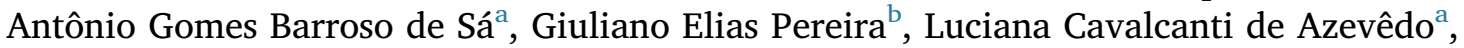 \\ Marcos dos Santos Lima ${ }^{a, *}$ \\ a Instituto Federal do Sertão Pernambucano, Departamento de Tecnologia em Alimentos, Campus Petrolina, Rod. BR 407 Km 08, S/N, Jardim São Paulo, CEP 56314-520, \\ Petrolina, PE, Brazil \\ b Empresa Brasileira de Pesquisa Agropecuária - Embrapa Semiárido/Uva e Vinho, Rodovia BR 428, Km 152, CP 23, CEP 56302-970 Petrolina, PE, Brazil
}

\section{A R T I C L E I N F O}

\section{Keywords:}

Food analysis

Food composition

Vitis labrusca $\mathrm{L}$

Beverage analysis

Wine

Grape juice

Sparkling wine

Sugars

Organic acids

\begin{abstract}
A B S T R A C T
Organic acids and sugars are related to the chemical balance of wines and grape juices, besides exerting a strong influence on the taste balance and sensorial acceptance by consumers. The aim of this study was to validate a method for the simultaneous determination of sugars and organic acids in wines and grape juices by highperformance liquid chromatography (HPLC) with refractive index detection (RID) and diode array detection (DAD) and to characterize commercial products from northeast Brazil. The method provided values for linearity $(\mathrm{R}>0.9982)$, precision $(\mathrm{CV} \%<1.4)$, recovery $(76-106 \%)$ and limits of detection $\left(0.003-0.044 \mathrm{~g} \mathrm{~L}^{-1}\right)$ and quantification $\left(0.008-0.199 \mathrm{~g} \mathrm{~L}^{-1}\right)$ which are considered acceptable for application in the characterization of these types of matrices. Principal components analysis (PCA) was used to verify the applicability of the method in the quality control of the products and resulted in the correct separation of the samples according to their type of processing. The results obtained in the characterization of the samples studied showed high levels of glucose and fructose in grape juice and the organic acids content was similar to those found in products originating from other regions around the world.
\end{abstract}

\section{Introduction}

Organic acids are primary metabolites present in grapes, and the profile and concentration of these compounds are important parameters in relation to the processing of grape juices and wines and the determination of their chemical composition (Ali et al., 2010). The content of acids, such as tartaric, malic and lactic, in these products directly influences the taste balance, chemical stability and $\mathrm{pH}$ (Silva et al., 2015). The presence of acetic acid, in particular, can be an indicator of microbiological changes or the use of low quality raw materials in the preparation of these products (Lima et al., 2014).

The analysis of organic acids in wines is necessary for quality control as well as to monitor the evolution of acidity during the different stages of winemaking, since important changes in wine can be detected by alterations in the acid content (Silva et al., 2015).

Regarding the bioactive capacity of organic acids, few studies have shown the beneficial effects of the consumption of foods rich in these compounds, with the exception of ascorbic acid, which has a high antioxidant power. However, citric and malic acids have significant protective effects on the myocardium and act on ischemic lesions, according to a study by Tang et al. (2013), where the importance of the addition of these compounds in the diet of patients under treatment for ischemic disease was highlighted.

Another group of primary metabolites present in grapes and related to the quality of juices and wines, are sugars. Glucose and fructose are the major sugars present in grapes and juices (Eyduran et al., 2015). In wines, due to the fermentation process, these compounds occur in low concentrations, and there is the presence of non-fermentable sugars such as xylose and arabinose. Grape derivatives may also contain sugars from the hydrolysis of polysaccharides through the action of pectinase enzymes, for instance, rhamnose (Apolinar-Valiente et al., 2015), and other sugars in small amounts, such as maltose (Morvai and MolnárPerl, 1992).

The profile and concentration of sugars and organic acids in grapes

\footnotetext{
* Corresponding author.

E-mail addresses: marcos.santos@ifsertao-pe.edu.br, marcoslima100@hotmail.com (M. dos Santos Lima).
} 
and grape derivatives, like juices and wines, are mainly dependent on factors such as grape maturation stage, region of origin, climate, variety, cultural practices and process conditions (Soyer et al., 2003; Muñoz-robredo et al., 2011; Ribeiro et al., 2012; Lima et al., 2015). The sub-mid São Francisco Valley (SFV), in northeast Brazil, is a new world region for the production of tropical wines. It differs from other regions in terms of its climatic conditions, with an average temperature of $26^{\circ} \mathrm{C}$, high sunlight intensity $(3000 \mathrm{~h}$ /year), and low annual rainfall (around $500 \mathrm{~mm}$ per year). The growth of grapes associated with crop irrigation management makes it possible for each vine to produce two harvests per year in this region (Padilha et al., 2016). Currently, the production of wines in the SFV is around 4 million liters per year, with 2.8 million liters $(70 \%)$ of sparkling wines, 1.16 million liters of red wines (29\%) and 40,000 Liters of white wines (1\%) (Pereira et al., 2016). The main varieties used in wine production are Cabernet Sauvignon, Syrah, Tempranillo, Touriga Nacional, Moscato Canelli, Chenin Blanc, Verdejo (Vitis vinifera L.) (Padilha et al., 2016).

In recent years, in the SFV, there has also been investment in the production of grape juice from new Brazilian varieties developed for the preparation of high quality juices, such as Isabel Precoce (Vitis labrusca) and hybrids ( $V$. labrusca $\times$ V. vinifera) BRS Violeta, BRS Cora and BRS Magna, and currently five companies produce around 1.5 million liters/ year of commercial juices with these varieties (Lima et al., 2014; Padilha et al., 2017).

Given the importance of sugars and organic acids in relation to the quality of grapes and grape-derived beverages, various procedures have been described for the determination of organic acids in musts and wines, which is usually performed by high performance liquid chromatography (HPLC). In general, RP-C18 columns are used for the separation of these compounds and the detection is carried out by ultraviolet (UV) detection, photodiode array detection (DAD) or mass spectrometry (MS) (Scherer et al., 2012; Ehling and Cole, 2011; Lima et al., 2015). For the determination of sugars in musts and wines, the International Vine and Wine Organization (OIV) recommends the HPLC method coupled with refractive index detection (RID) (OIV, 2011).

Multivariate statistical analysis techniques have proven to be powerful tools when investigating complex samples such as wine (Saurina, 2010). Principal component analysis (PCA) is one of the most commonly used techniques in multivariate analysis, aimed at reducing a dataset to its main components and visualizing similarities (Vanhatalo and Kulahci, 2015). PCA has been used in several studies, for instance, to interpret data related to chemical and sensorial profiles (Parpinello et al., 2015) and to distinguish the varietal and/or geographical origin (Ziółkowska et al., 2016) of grape pomaces and wines.

Few methods described in the literature involve the simultaneous determination of sugars and organic acids in grape juice and wine by HPLC. Some previously published methods for the simultaneous determination of these compounds in grapes, wine and alcoholic beverages fermented from fruits involve the separation of these metabolites with the use of ion exchange columns $(300 \times 7.78 \mathrm{~mm})$ filled with sulfonated resin particles, crosslinked styrene-divinylbenzene copolymer in the hydrogen form, 7 to $11 \mu \mathrm{m}$ in diameter. An isocratic phase comprised of acidified ultrapure water was used and the temperatures ranged from 25 to $75{ }^{\circ} \mathrm{C}$. The detection of sugars is usually carried out by RID and for organic acids UV detection or DAD, at between 210 and $215 \mathrm{~nm}$, is used (Lopez and Gomez, 1996; Chinnici et al., 2005; Kelebek et al., 2009; Eyéghé-Bickong et al., 2012). In this context, the aim of this study was to validate the methodology for the simultaneous determination of the main sugars and organic acids present in wines and grape juices by HPLC-DAD-RID and characterize samples from the submid São Francisco Valley (SFV), northeast Brazil. Additionally, principal component analysis (PCA) was applied in the characterization of the data to demonstrate the applicability of the method in the quality control of these products.

\section{Material and methods}

\subsection{Chemicals}

Glucose and fructose were obtained from Sigma-Aldrich (St. Louis, MO, USA). Maltose and rhamnose were obtained from Chem Service (West Chester, PA, USA). Tartaric, malic, lactic, citric and acetic acids were obtained from Química Vetec (Rio de Janeiro, Brazil), all with a purity level of $\geq 98 \%$. Ultrapure water was obtained from a Millipore Milli-Q system (Bedford, MA, USA). Sulfuric acid was obtained from Merck (Darmstadt, Germany).

\subsection{Samples}

To validate the methodology, commercial samples of grape juice and wine from the SFV $\left(09^{\circ} 16^{\prime} 20^{\prime \prime}\right.$ South latitude and $40^{\circ} 52^{\prime} 8^{\prime \prime}$ West longitude) were analyzed. The sample characterization was carried out using a previously validated method and 12 commercial products from local companies were collected. For each sample, 3 bottles of different batches were purchased, totalizing 36 samples. The commercial products, originated from five wineries, correspond to seven labels of red wines produced with the varieties 'Barbera', 'Touriga Nacional', 'Petit Verdot', 'Ruby Cabernet', 'Syrah', and 'Tempranillo' and a mixture of cultivars 'Cabernet Sauvignon', 'Syrah' and 'Alicante Bouschet', which was called Assemblage, two labels of sparkling Asti-type muscatel produced with the varieties 'Moscato Canelli' and 'Moscato Italia', a white wine label 'Chenin Blanc' and two grape juice samples (Vitis labrusca L.) made with new Brazilian grape varieties ('Isabel Precocce', 'BRS Cora' and 'BRS Violeta'). Classical analysis techniques were used to determine the $\mathrm{pH}$ (potentiometer/pH analyzer, Tecnal, Piracicaba, SP, Brazil), soluble solids ( ${ }^{\circ}$ Brix) (digital refractometer HI 96801, Hanna Instruments, Ann Arbor, MI, USA), titratable acidity and alcoholic strength of the grape juice and wine samples (OIV, 2011) (see Table 1).

\subsection{Equipment and analytical procedure}

The analysis were performed using an Agilent HPLC system, model 1260 Infinity LC (Agilent Technologies, Santa Clara, CA, USA) equipped with a quaternary solvent pump (G1311C model), degasser, thermostatted column compartment (G1316A model) and autosampler (model G1329B) coupled to a diode array detector (DAD) (G1315D model) and refractive index detector (RID) (G1362A model). Data were processed using OpenLAB CDS ChemStation Edition ${ }^{\mathrm{TM}}$ software (Agilent Technologies).

The analytical procedure was performed applying the chromatographic conditions previously described by Ball (2011), optimized for wine and grape juice matrices. A $500 \mu \mathrm{L}$ aliquot of wine or grape juice was diluted in $1.0 \mathrm{~mL}$ of ultrapure water, filtered through a $0.45 \mu \mathrm{m}$ nylon membrane (Allcrom-Phenomenex, Torrance, CA, USA), and a volume of $10 \mu \mathrm{L}$ was injected. The ion exchange column was an Agilent Hi-Plex $\mathrm{H}(300 \times 7.7 \mathrm{~mm})$ with internal particles of $8.0 \mu \mathrm{m}$ protected by a PL Hi-Plex H $(5 \times 3 \mathrm{~mm})$ guard column (Agilent Technologies, Santa Clara, CA, USA). The temperature of the column compartment was maintained at $70{ }^{\circ} \mathrm{C}$ and the RID flow cell was kept at $50{ }^{\circ} \mathrm{C}$. The flowrate applied was $0.5 \mathrm{~mL} \mathrm{~min}^{-1}$ with a run time of $20 \mathrm{~min}$. The phase was $4.0 \mathrm{mM} \mathrm{L}^{-1} \mathrm{H}_{2} \mathrm{SO}_{4}$ in ultrapure water.

Standard solutions were injected to obtain the retention time for each compound. For the determination of tartaric, malic, lactic, citric and acetic acids, detection was conducted in the DAD at $210 \mathrm{~nm}$. For the sugars maltose, glucose, fructose and rhamnose sugar, detection was carried out by RID.

The chromatograms obtained for the standard solutions of the organic acids and sugars can be seen in Fig. 1 . 
Table 1

Characteristics of samples studied.

\begin{tabular}{|c|c|c|c|c|c|c|}
\hline Sample code & Type & Grape variety & $\mathrm{pH}$ & Soluble solids $\left({ }^{\circ} \mathrm{Brix}\right)$ & $\begin{array}{l}\text { Alcoholic strength (\%v/ } \\
\text { v) }\end{array}$ & $\begin{array}{l}\text { Titratable acidity } \\
\left(\mathrm{mEq} \mathrm{L}^{-1}\right)\end{array}$ \\
\hline ASB & Red wine & $\begin{array}{l}60 \% \text { Cabernet Sauvignon, } 30 \% \text { Syrah, } 10 \% \\
\text { Alicante Bouschet }\end{array}$ & $3.64 \pm 0.06$ & - & $12.6 \pm 0.4$ & $98 \pm 2$ \\
\hline BAR & Red wine & $100 \%$ Barbera & $3.60 \pm 0.04$ & - & $13.0 \pm 0.1$ & $87 \pm 2$ \\
\hline $\mathrm{TN}$ & Red wine & $100 \%$ Touriga Nacional & $3.60 \pm 0.02$ & - & $13.1 \pm 0.1$ & $101 \pm 3$ \\
\hline PEV & Red wine & $100 \%$ Petit Verdot & $3.93 \pm 0.03$ & - & $13.8 \pm 0.3$ & $105 \pm 5$ \\
\hline RCA & Red wine & $100 \%$ Ruby Cabernet & $4.09 \pm 0.04$ & - & $12.0 \pm 0.1$ & $76 \pm 3$ \\
\hline SYR & Red wine & $100 \%$ Syrah & $3.71 \pm 0.05$ & - & $13.6 \pm 0.3$ & $83 \pm 2$ \\
\hline TEM & Red wine & $100 \%$ Tempranillo & $3.86 \pm 0.03$ & - & $13.1 \pm 0.2$ & $99 \pm 2$ \\
\hline MOC & $\begin{array}{l}\text { Sparkling muscatel } \\
\text { (Asti) }\end{array}$ & $100 \%$ Moscato Canelli & $3.52 \pm 0.02$ & - & $7.2 \pm 0.1$ & $63 \pm 4$ \\
\hline MOI & $\begin{array}{l}\text { Sparkling muscatel } \\
\text { (Asti) }\end{array}$ & 100\% Moscato Itália & $3.32 \pm 0.01$ & - & $7.3 \pm 0.1$ & $67 \pm 2$ \\
\hline CHE & White wine & $100 \%$ Chenin Blanc & $3.56 \pm 0.02$ & - & $12.8 \pm 0.1$ & $70 \pm 3$ \\
\hline IPBV & Grape juice & $80 \%$ Isabel Precoce, $20 \%$ BRS Violeta & $3.65 \pm 0.04$ & $20.0 \pm 0.3$ & - & $107 \pm 2$ \\
\hline IPBC & Grape juice & $80 \%$ Isabel Precoce, $20 \%$ BRS Cora & $3.34 \pm 0.02$ & $18.6 \pm 0.6$ & - & $109 \pm 2$ \\
\hline
\end{tabular}

Results are expressed as mean \pm standard deviation (independent samples, $\mathrm{N}=3$ ).

\subsection{Validation of the method}

The validation parameters, according to the guide for validation and analytical quality control published of the Brazilian Ministry of Agriculture (Brasil, 2011), obtained from assays with standard solutions, blank samples and spiked samples, were the calibration curve linearity, precision, accuracy, recovery and limits of detection and quantification.

\subsubsection{Linearity}

The range of linearity was established by injecting six different concentrations obtained by the dilution of a standard mixture of organic acids and sugars in ultrapure water. The concentration range was consistent with that proposed by Lopez and Gomez (1996) and EyéghéBickong et al. (2012) for wines and grape must. For tartaric, malic, lactic and citric acids, the range was found to be 0.025 to $5.0 \mathrm{~g} \mathrm{~L}^{-1}$, and for acetic acid it was 0.010 to $2.0 \mathrm{~g} \mathrm{~L}^{-1}$. The range for glucose and fructose sugars was $0.10-20.0 \mathrm{~g} \mathrm{~L}^{-1}$, and for maltose and rhamnose it was $0.025-5.0 \mathrm{~g} \mathrm{~L}^{-1}$. Analytical curves for each sugar and organic acid were obtained considering the correlation between the peak area and the respective concentration of the standard using a linear least squares model.

\subsubsection{Method accuracy and recovery}

Accuracy was evaluated by the coefficient of variation (CV\%) obtained from the results of six injections of $500 \mu \mathrm{L}$ of the wine/grape juice mixture

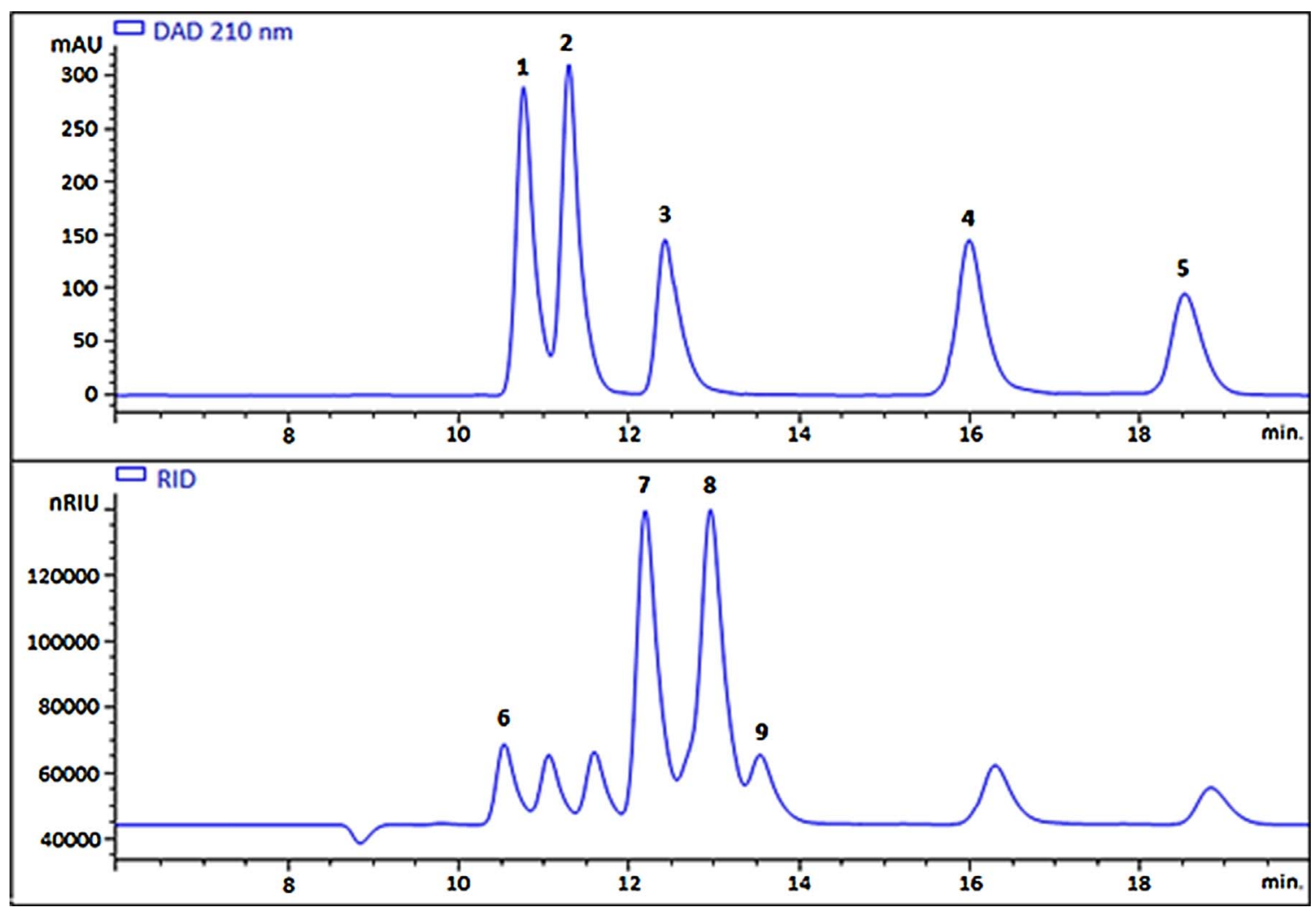

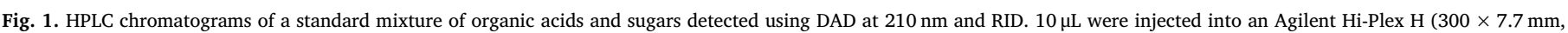

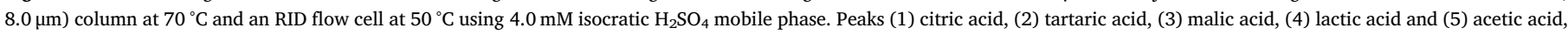
(6) maltose, (7) glucose, (8) fructose and (9) rhamnose. 
with $1.0 \mathrm{~mL}$ of a buffer solution containing tartaric, malic, lactic and citric acids in a concentration of $2.5 \mathrm{~g} \mathrm{~L}^{-1}$, acetic acid at $1.0 \mathrm{~g} \mathrm{~L}^{-1}$, glucose and fructose at $10.0 \mathrm{~g} \mathrm{~L}^{-1}$, and maltose and rhamnose at $2.5 \mathrm{~g} \mathrm{~L}^{-1}$. The recovery was calculated comparing the result obtained analytically for each compound with the initial concentration in the spiked sample.

\subsubsection{Determination of detection limits and method quantification}

To obtain the limits of detection (LOD) and quantification (LOQ), the method described by Hubaux and Vos (1970) was used. Three standards were prepared at concentrations close to the estimated LOD and analyzed in triplicate. An analytical curve was constructed by plotting the values obtained from the analysis of the standards versus the actual values, obtaining the slope of the curve, intercept and coefficient of correlation. The residual standard deviation (RSD) was calculated by comparing the values obtained in the analysis with the actual values. The LOD and LOQ were established as 3 and 10 times the $\mathrm{RSD}$, respectively, added to the intercept of the curve.

\subsection{Characterization of wines and grape juices and statistical analysis}

A validated method was used to characterize the sugars and organic acids in commercial products from the sub-mid São Francisco Valley (Table 1). The analysis was performed in triplicate and the results obtained were represented as the average \pm standard deviation. Principal component analysis (PCA) was also performed to relate the organic acids and sugars to the different types of wines and grape juices evaluated. Statistical analysis was performed using SPSS version 17.0 for Windows (SPSS, Chicago, IL, USA).

\section{Results and discussion}

\subsection{Validation of the method applied}

The validation of a single condition for the simultaneous analysis of organic acids and sugars represents a useful and rapid solution for the study of the presence of these metabolites in grape matrices such as juices and wines.

Different chromatographic conditions were tested for the separation of the compounds and the best conditions were used for the method validation and the characterization of the samples studied (Fig. 2).

\subsection{Linearity, accuracy and method recovery}

The results for the validation parameters in the determination of sugars and organic acids can be seen in Table 2. The data obtained showed a good linear range where the values for the correlation coefficient (R) were 0.9982-1.0000. According to Brasil (2011), the R values for the calibration curves must be greater than 0.99 , which verifies that the linearity obtained in this study for the response to external standards is adequate for the intended purpose.

The accuracy parameter showed a coefficient of variation (CV\%) ranging from 0.1 to 1.0 for grape juice and from 0.1 to 1.4 for wine. The CV\% values obtained for the 9 compounds studied were lower than the maximum limit of $20 \%$ established by Brazilian legislation for the concentration ranges studied (Brasil, 2011).

The highest and lowest recovery percentages (RC\%) for the grape juice of 76.3 and 106.4 were observed for rhamnose and glucose, respectively, while the RC\% values for the wine ranged from 89.6 to 101 (citric acid and rhamnose, respectively). These values are in agreement with the limits established by Brazilian legislation (80-107\%), with the exception of rhamnose (Brasil, 2011), and were also similar to those obtained by several authors under different chromatographic conditions for the validation of methods for the determination of organic acid and sugars in juices and wines by HPLC-UV (Lima et al., 2010), HPLCDAD (Scherer et al., 2012), HPLC-MS (Ehling and Cole, 2011) and HPLC-UV-RID (Chinnici et al., 2005).

\subsection{Limits of detection (LOD) and quantification (LOQ)}

To obtain the LOD and LOQ (Table 2), the residual standard deviation (RSD) values were multiplied by 3 and 10 respectively, and the result was added to the curve intercept close to the estimated LOD (Hubaux and Vos, 1970). RSD values ranged from 0.001 to 0.021 for acetic acid and fructose, respectively, while the LOD and LOQ values were $0.003-0.050 \mathrm{~g} \mathrm{~L}^{-1}$ and $0.008-0.199 \mathrm{~g} \mathrm{~L}^{-1}$, respectively.

The LOD and LOQ are used to demonstrate the ability of a method to detect and quantify low concentrations of a substance, respectively (Eurachem, 2014). The LOD and LOQ values obtained in this study are in agreement with those found in other validation studies for the determination of organic acids and sugars in juices and wines by HPLC (Lopez and Gomez, 1996; Chinnici et al., 2005; Eyéghé-Bickong et al., 2012).

The LOD and LOQ values were considered suitable for the use of this methodology in quality control and scientific research related to these metabolites in juices and wines, since they are lower than those reported for the official methodology recommended by the International Vine and Wine Organization (OIV, 2011) for the analysis in these matrices.

3.4. Characterization of commercial products of the sub-mid São francisco valley, northeast Brazil

\subsubsection{Organic acids}

The results obtained for organic acids are reported in Table 3. The total acid quantified in the samples ranged from 3.60 to $7.58 \mathrm{gL}^{-1}$. Tartaric acid was the main acid present in wines and juices, with values of 0.63 to $5.63 \mathrm{~g} \mathrm{~L}^{-1}$, which represented over $50 \%$ of the total acids quantified. The concentration of malic acid in the grape juice samples ranged from 1.56 to $1.92 \mathrm{~g} \mathrm{~L}^{-1}$, and for the wines this acid ranged from $<0.007$ to $3.18 \mathrm{~g} \mathrm{~L}^{-1}$.

Several studies have reported that the main acid present in grape juices and wines is tartaric acid, with concentrations ranging from 0.80 to $12.7 \mathrm{~g} \mathrm{~L}^{-1}$ for juices, and 0.95 to $6.50 \mathrm{~g} \mathrm{~L}^{-1}$ for wines (Soyer et al., 2003; Muñoz-robredo et al., 2011; Ehling and Cole, 2011; Eyduran et al., 2015; Lima et al., 2015). The sum of the tartaric and malic acids can represent more than $80 \%$ of the total amount of acid in grapes and juices, and their concentrations vary depending on the stage of maturation, grape variety, climate, and factors related to the processing such as the application of tartaric acid stabilization, which results in a decrease in the concentration of tartaric acid (Ribeiro et al., 2012; Soyer et al., 2003).

Lactic acid was not detected in the grape juices. However, in the wine samples, it ranged from 0.13 to $3.40 \mathrm{~g} \mathrm{~L}^{-1}$. With regard to citric acid, the values found in wines and grape juices ranged from $<0.021$ to $1.16 \mathrm{~g} \mathrm{~L}^{-1}$. Acetic acid was not quantified in the grape juice samples, but in the wine samples the percentages varied from 0.04 to $0.28 \mathrm{~g} \mathrm{~L}^{-1}$. The low concentrations of citric acid $(<0.021$ for five of the seven samples of red wine) could be due to the fact that this acid is converted into malic acid during maturation. Furthermore, in wines, malic acid can be used by lactic acid bacteria during malolactic fermentation, when it is transformed into lactic acid (Mato et al., 2007), which explains the lactic acid values (1.24 to $3.40 \mathrm{~g} \mathrm{~L}^{-1}$ ) obtained for the red wines.

The presence of acetic acid in high concentrations in juices and wines is indicative of undesirable fermentations which may be caused by a lack of hygienic associated with the raw material or fermentation processes being carried out by undesirable microorganisms (Lima et al., 2014). However, the values obtained for the samples were acceptable, since Brazilian legislation sets limits of 0.25 and $1.50 \mathrm{~g} \mathrm{~L}^{-1}$ for grape juices and wines, respectively (Brasil, 2004).

The values for organic acids obtained for the red wines and grape juices in this study are in agreement with the aforementioned literature data on products obtained from the sub-mid SFV (Lima et al., 2010, 

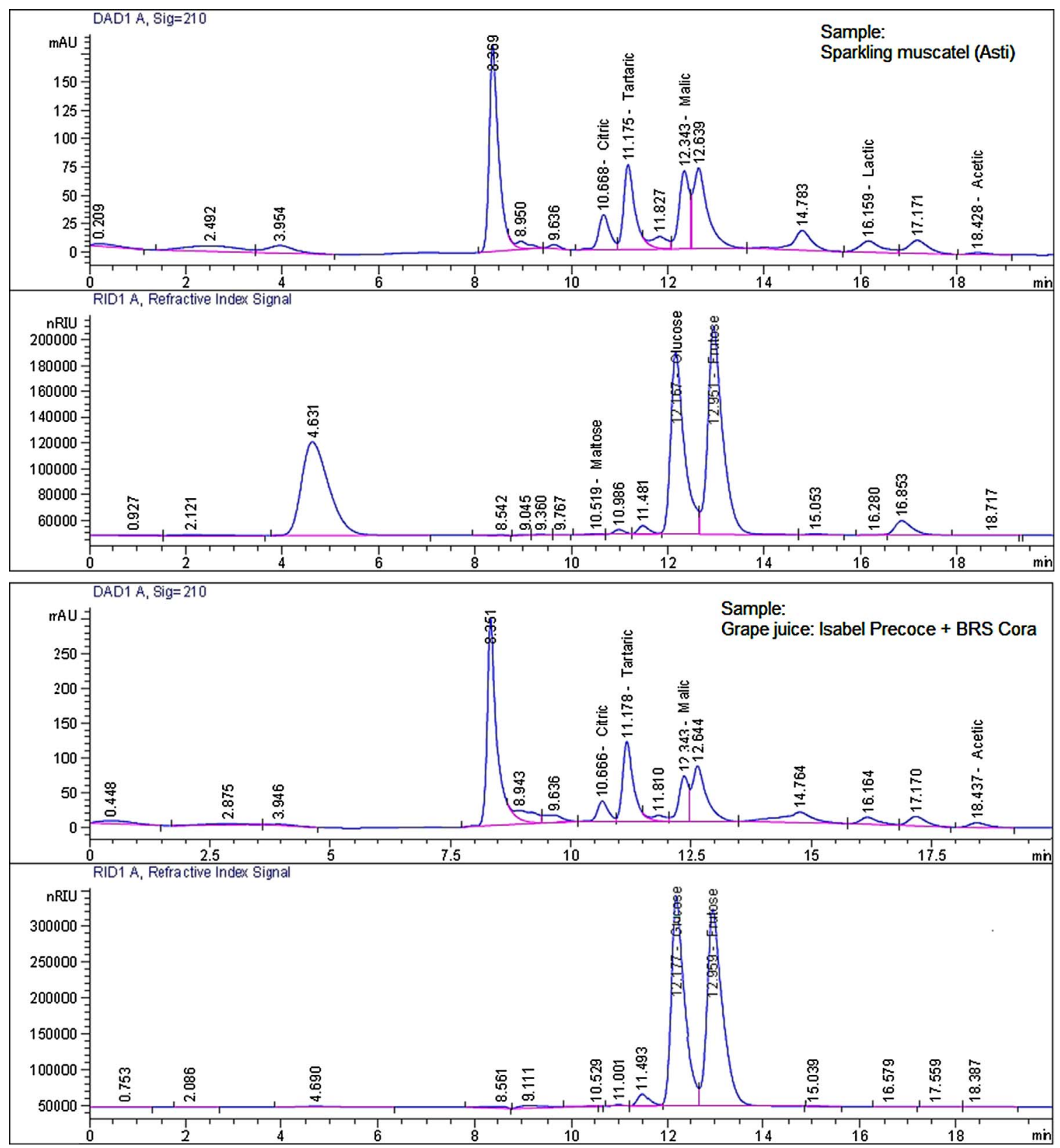

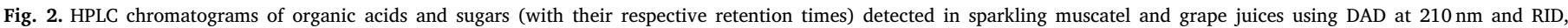
respectively.

2014), which is evidence of the reliability of the analytical protocol used.

In regions with a tropical climate, such as the SFV, where high temperatures and insolation dominate, the metabolism favors the synthesis and accumulation of sugars in the berries, as well as an expressive decrease in organic acids (Ribeiro et al., 2012). However, the values obtained for the organic acids in the samples analyzed are consistent with those reported for juices from temperate climate regions in Brazil (Rizzon and Miele, 2012) and Spanish wines (Regmi et al., 2012).

The profile and concentration of organic acids are important parameters for evaluating the processing and chemical composition of grape juices and wines, because when these compounds are present they cause a reduction in the $\mathrm{pH}$ of the product. This, in turn, increases the color stability, since anthocyanins retain their red color at low $\mathrm{pH}$, and ensures the balance between acid and sweet tastes (Silva et al., 2015).

\subsubsection{Sugars}

The results obtained for the sugars analysis are shown in Table 4. The total sugars contents was $163.31-200.97 \mathrm{~g} \mathrm{~L}^{-1}$ in the grape juices, $0.27-6.42 \mathrm{~g} \mathrm{~L}^{-1}$ in the red wines and $66.21-70.25 \mathrm{~g} \mathrm{~L}^{-1}$ in the sparkling Asti-type muscatel wines. With regard to the glucose and fructose in the grape juices, the values ranged from 86.61 to 108.09 and from 76.4 to $92.9 \mathrm{~g} \mathrm{~L}^{-1}$, respectively. In the red and white wines, the glucose and fructose content were less than 1.23 and $4.97 \mathrm{~g} \mathrm{~L}^{-1}$, respectively. The values for the sparkling muscatels ranged from 21.39 to $35.5 \mathrm{~g} \mathrm{~L}^{-1}$ and from 35.2 to $45.12 \mathrm{~g} \mathrm{~L}^{-1}$ for glucose and fructose, respectively.

The levels of glucose and fructose in the juices analyzed were higher than those reported for grape juices in southern Brazil (i.e., temperate climates), where the values reported for the sum of glucose and fructose range from 133 to $167 \mathrm{~g} \mathrm{~L}^{-1}$ (Rizzon and Miele, 2012). The high levels of glucose and fructose in the juice observed in this study suggest that these products originated from a semi-arid tropical climate, as is the 
Table 2

Validation parameters for simultaneous determination of organic acids and sugars in wine and grape juice by HPLC-DAD-RID.

\begin{tabular}{|c|c|c|c|c|c|c|c|c|c|c|c|}
\hline \multirow{2}{*}{$\begin{array}{l}\text { Organic acids DAD } \\
210 \mathrm{~nm}\end{array}$} & \multirow[t]{2}{*}{ RT (min) } & \multirow{2}{*}{$\begin{array}{l}\text { Range }\left(\mathrm{g} \mathrm{L}^{-1}\right) \\
(\mathrm{N}=6)\end{array}$} & \multirow[t]{2}{*}{ Calibration curve } & \multirow[t]{2}{*}{$\mathrm{R}$} & \multicolumn{2}{|c|}{ Precision $(\mathrm{CV} \%)(\mathrm{N}=6)$} & \multicolumn{2}{|c|}{$\%$ Recovery $(\mathrm{N}=6)$} & \multirow[t]{2}{*}{ RSD } & \multirow[t]{2}{*}{ LOD } & \multirow[t]{2}{*}{ LOQ } \\
\hline & & & & & Grape juice & Red wine & Grape juice & Red wine & & & \\
\hline Tartaric & 11.30 & $0.025-5.0$ & $Y=1949.80 X+7.36$ & 0.9999 & 0.6 & 1.4 & 94.8 & 96.1 & 0.007 & 0.026 & 0.071 \\
\hline Malic & 12.43 & $0.025-5.0$ & $\mathrm{Y}=1235.18 \mathrm{X}+1.38$ & 0.9999 & 0.1 & 1.0 & 99.4 & 94.1 & 0.003 & 0.007 & 0.026 \\
\hline Citric & 10.76 & $0.025-5.0$ & $Y=1617.67 X+0.9996$ & 0.9996 & 0.8 & 0.2 & 99.1 & 89.6 & 0.009 & 0.021 & 0.096 \\
\hline Lactic & 16.00 & $0.025-5.0$ & $Y=1408.69 X+0.05$ & 1.0000 & 0.2 & 0.3 & 90.1 & 91.5 & 0.005 & 0.02 & 0.056 \\
\hline Acetic & 18.54 & $0.01-2.0$ & $Y=2418.65 X-1.22$ & 1.0000 & 0.1 & 0.1 & 95.8 & 96.0 & 0.001 & 0.003 & 0.008 \\
\hline \multicolumn{12}{|l|}{ Sugars RID } \\
\hline Glucose & 12.19 & $0.1-20.0$ & $\begin{array}{l}Y=157077.87 X- \\
2011.42\end{array}$ & 0.9999 & 0.2 & 1.4 & 106.4 & 91.1 & 0.012 & 0.021 & 0.103 \\
\hline Fructose & 12.96 & $0.1-20.0$ & $Y=196875 X-4866.19$ & 0.9999 & 0.3 & 0.1 & 97.7 & 91.2 & 0.021 & 0.05 & 0.199 \\
\hline Maltose & 10.54 & $0.025-5.0$ & $\begin{array}{l}Y=141503.64 \\
X+5557.19\end{array}$ & 0.9982 & 0.2 & 1.2 & 86.3 & 98.1 & 0.011 & 0.037 & 0.114 \\
\hline Rhamnose & 13.54 & $0.025-5.0$ & $\begin{array}{l}Y=159350.09 \\
X-2385.92\end{array}$ & 0.9999 & 1.0 & 0.7 & 76.3 & 100.8 & 0.015 & 0.044 & 0.151 \\
\hline
\end{tabular}

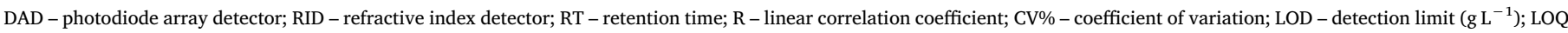
- quantification limit $\left(\mathrm{g} \mathrm{L}^{-1}\right)$; RSD - residual standard deviation.

case in the SFV, providing a more pronounced sensorial characteristic in relation to the "sweet taste".

For the Asti-type muscatels, the glucose and fructose values are consistent with the specific characteristics required for the product. Brazilian legislation states that this type of drink must be produced exclusively with grapes of the Moscato genus by single fermentation in pressure tanks or bottles and have a sugar residue of at least $60 \mathrm{~g} \mathrm{~L}^{-1}$ (Brasil, 2004).

The higher values for fructose compared to glucose, obtained for the wine samples, can be explained by the preference of Saccharomyces cerevisiae yeasts to ferment glucose, resulting in larger residual amounts of fructose in fermented grapes (Tronchoni et al., 2009).

Maltose was present in small concentrations in practically all samples analyzed with amounts ranging from 0.04 to $0.58 \mathrm{~g} \mathrm{~L}^{-1}$. In a study by Morvai and Molnár-Perl (1992), values of approximately $0.16 \mathrm{~g}^{-1} 100 \mathrm{~g}$ maltose are reported for grape must. Rhamnose was only present in four samples of red wine, with values ranging from 0.05 to $0.24 \mathrm{~g} \mathrm{~L}^{-1}$, and these results are in agreement with those reported by Apolinar-Valiente et al. (2015) for red wines produced from Cabernet Sauvignon, Syrah and Monastrell grapes in southeastern Spain.

With regard to wine quality, some oligosaccharides have physicochemical properties, such as the ability to chelate cations (Cescutti and Rizzo, 2001). Quijada-Morín et al. (2014) reported that high rhamnose concentrations would reduce the perceived astringency in Tempranillo wines.

\subsubsection{Principal components analysis (PCA)}

Principal components analysis (PCA) was applied to the different types of products analyzed, on the basis of their contents of sugars and acids quantified by the methodology described, resulting in 9 major components. Principal components 1 and 2 (PC1 and PC2, respectively) explained $78.9 \%$ of the experimental variance, where PC1 explained $50.2 \%$ and PC2 explained $28.9 \%$ (Fig. 3). Factorial analysis revealed that the main compounds which separated the samples analyzed in PC1 were lactic and acetic acids (positive loading $>0.70$ ), and glucose, fructose and citric acid (negative loading $>0.70$ ). In the case of PC2, the compounds responsible for the separation were malic acid and maltose (positive loading $>0.70$ ). PC1 and PC2 components separated the products into three distinctive groups. PC1, with a higher explained variance weighting $(50.2 \%)$, separated, in the positive part, a group formed of red wines (ASB, BAR, TN, PEV, RCA, SYR and TEM), which were associated with higher amounts of lactic and acetic acids. On the downside, PC1 separated another group formed by grape juices (IPBC and IPBV) and sparkling Asti-type muscatel (MOI and MOC), associated with higher values for glucose, fructose and citric acid. Component 2 (PC2) separated Chenin Blanc white wine (CHE), which was associated

Table 3

Organic acids content of samples analyzed using the proposed method.

\begin{tabular}{|c|c|c|c|c|c|c|}
\hline \multirow[t]{2}{*}{ Samples } & \multicolumn{6}{|c|}{ Organic acids $\left(\mathrm{g} \mathrm{L}^{-1}\right)^{\mathrm{a}}$} \\
\hline & Tartaric & Malic & Lactic & Citric & Acetic & $\Sigma$ Organic acids quantified \\
\hline \multicolumn{7}{|l|}{ Red wines } \\
\hline Assemblage & $4.39 \pm 0.33$ & $<0.007$ & $1.71 \pm 0.01$ & $<0.021$ & $0.16 \pm 0.00$ & $6.27 \pm 0.34$ \\
\hline Barbera & $3.20 \pm 0.00$ & $<0.007$ & $2.28 \pm 0.00$ & $<0.021$ & $0.25 \pm 0.03$ & $5.86 \pm 0.00$ \\
\hline Touriga Nacional & $3.11 \pm 0.00$ & $1.56 \pm 0.00$ & $1.36 \pm 0.04$ & $<0.021$ & $0.15 \pm 0.00$ & $6.18 \pm 0.03$ \\
\hline Petit Verdot & $0.63 \pm 0.10$ & $1.48 \pm 0.01$ & $3.40 \pm 0.12$ & $<0.021$ & $0.28 \pm 0.00$ & $5.80 \pm 0.22$ \\
\hline Ruby Cabernet & $5.63 \pm 0.05$ & $0.06 \pm 0.00$ & $1.75 \pm 0.00$ & $<0.021$ & $0.15 \pm 0.00$ & $7.58 \pm 0.04$ \\
\hline Syrah & $1.87 \pm 0.01$ & $<0.037$ & $1.24 \pm 0.00$ & $0.32 \pm 0.00$ & $0.17 \pm 0.00$ & $3.60 \pm 0.00$ \\
\hline Tempranillo & $3.57 \pm 0.01$ & $<0.037$ & $2.16 \pm 0.10$ & $1.16 \pm 0.00$ & $0.18 \pm 0.00$ & $7.09 \pm 0.09$ \\
\hline \multicolumn{7}{|l|}{ Sparkling muscatel (Asti) } \\
\hline Moscato Canelli & $1.92 \pm 0.04$ & $1.62 \pm 0.06$ & $0.41 \pm 0.05$ & $0.50 \pm 0.02$ & $0.14 \pm 0.00$ & $4.61 \pm 0.15$ \\
\hline Moscato Itália & $1.30 \pm 0.02$ & $1.70 \pm 0.03$ & $0.44 \pm 0.00$ & $0.56 \pm 0.01$ & $0.04 \pm 0.00$ & $4.03 \pm 0.07$ \\
\hline \multicolumn{7}{|l|}{ White wine } \\
\hline Chenin Blanc & $0.77 \pm 0.00$ & $3.18 \pm 0.02$ & $0.13 \pm 0.00$ & $0.36 \pm 0.00$ & $0.06 \pm 0.00$ & $4.48 \pm 0.00$ \\
\hline \multicolumn{7}{|l|}{ Grape Juice } \\
\hline Isabel Precoce + BRS Violeta & $5.38 \pm 0.01$ & $1.56 \pm 0.00$ & $<0.02$ & $0.41 \pm 0.00$ & $<0.003$ & $7.35 \pm 0.00$ \\
\hline Isabel Precoce + BRS Cora & $4.02 \pm 0.00$ & $1.92 \pm 0.03$ & $<0.02$ & $0.25 \pm 0.02$ & $<0.003$ & $6.20 \pm 0.05$ \\
\hline
\end{tabular}

\footnotetext{
${ }^{\text {a }}$ Results are expressed as mean \pm standard deviation (independent samples, $\mathrm{N}=3$ ).
} 
Table 4

Sugar content of samples analyzed using the proposed method.

\begin{tabular}{|c|c|c|c|c|c|}
\hline \multirow[t]{2}{*}{ Samples } & \multicolumn{5}{|l|}{ Sugars $\left(g^{-1}\right)^{a}$} \\
\hline & Glucose & Fructose & Maltose & Rhamnose & $\Sigma$ Sugar quantified \\
\hline \multicolumn{6}{|l|}{ Red wines } \\
\hline Assemblage & $1.23 \pm 0.17$ & $0.82 \pm 0.42$ & $0.20 \pm 0.00$ & $0.05 \pm 0.05$ & $2.30 \pm 0.53$ \\
\hline Barbera & $<0.021$ & $0.43 \pm 0.00$ & $0.44 \pm 0.00$ & $<0.044$ & $0.88 \pm 0.00$ \\
\hline Touriga Nacional & $1.19 \pm 0.01$ & $<0.05$ & $0.31 \pm 0.00$ & $<0.044$ & $1.50 \pm 0.00$ \\
\hline Petit Verdot & $0.04 \pm 0.00$ & $0.16 \pm 0.14$ & $0.11 \pm 0.09$ & $0.24 \pm 0.06$ & $0.73 \pm 0.11$ \\
\hline Ruby Cabernet & $<0.021$ & $<0.05$ & $0.14 \pm 0.00$ & $0.14 \pm 0.00$ & $0.27 \pm 0.00$ \\
\hline Syrah & $0.20 \pm 0.00$ & $0.73 \pm 0.00$ & $0.37 \pm 0.00$ & $0.22 \pm 0.00$ & $1.52 \pm 0.00$ \\
\hline Tempranillo & $0.07 \pm 0.00$ & $0.59 \pm 0.00$ & $0.49 \pm 0.00$ & $<0.044$ & $1.15 \pm 0.00$ \\
\hline \multicolumn{6}{|l|}{ Sparkling muscatel (Asti) } \\
\hline Moscato Canelli & $21.39 \pm 0.01$ & $45.12 \pm 0.28$ & $0.04 \pm 0.00$ & $<0.044$ & $66.21 \pm 0.03$ \\
\hline Moscato Itália & $35.50 \pm 0.02$ & $35.20 \pm 0.02$ & $0.24 \pm 0.20$ & $<0.044$ & $70.75 \pm 0.03$ \\
\hline \multicolumn{6}{|l|}{ White wine } \\
\hline Chenin Blanc & $0.88 \pm 0.00$ & $4.97 \pm 0.00$ & $0.58 \pm 0.00$ & $<0.044$ & $6.42 \pm 0.00$ \\
\hline \multicolumn{6}{|l|}{ Grape juice } \\
\hline Isabel Precoce + BRS Violeta & $108.09 \pm 0.00$ & $92.90 \pm 0.02$ & $<0.037$ & $<0.044$ & $200.97 \pm 0.00$ \\
\hline Isabel Precoce + BRS Cora & $86.61 \pm 0.36$ & $76.40 \pm 0.28$ & $0.16 \pm 0.13$ & $<0.044$ & $163.31 \pm 0.64$ \\
\hline
\end{tabular}

${ }^{\text {a }}$ Results are expressed as mean \pm standard deviation (independent samples, $\mathrm{N}=3$ ).

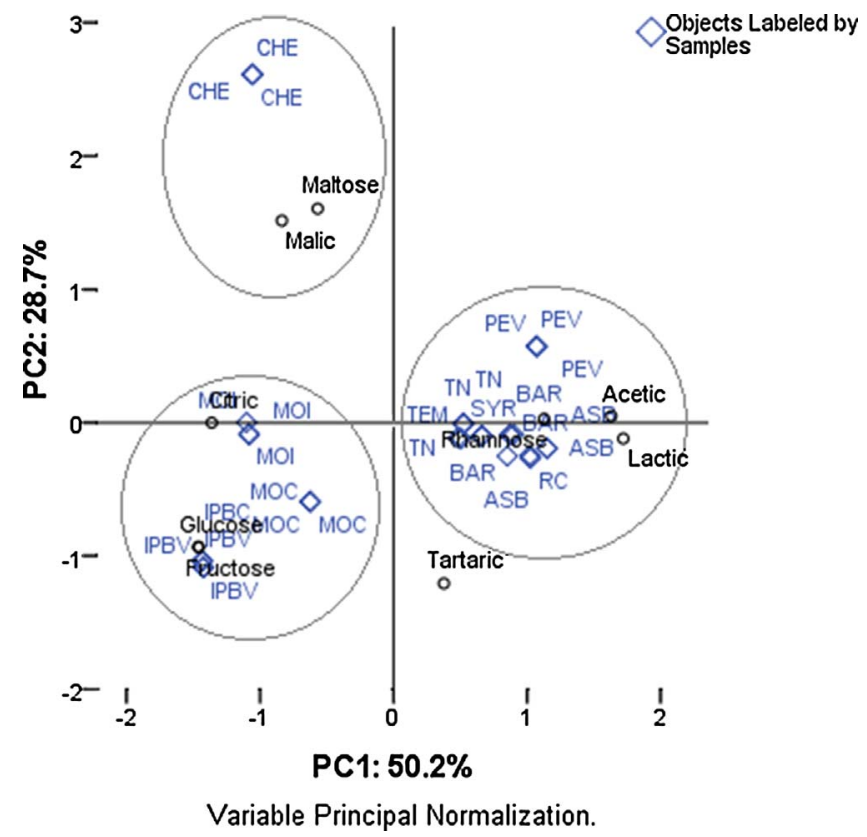

Fig. 3. Principal component analysis of data on sugars and organic acids. ASB: Assemblage; BAR: Barbera; TN: Touriga Nacional; PEV: Petit Verdot; RC: Ruby Cabernet; SYR: Syrah; TEM: Tempranillo; MCA: Moscato Canelli; MIT: Moscato Italia; CHE: Chenin Blanc; IPBV $=$ Blend Isabel Precoce $80 \%$ and BRS Violeta $20 \%$ and IPBC $=$ Blend Isabel Precoce $80 \%$ and BRS Cora $20 \%$.

with higher concentrations of malic acid and maltose.

The separation of the products according to the characterization of sugars and organic acids is expected, since it is known that during the fermentation of the must from grapes used to produce red wines glucose and fructose are consumed (alcoholic fermentation), generating mainly ethanol and other substances, such as acetic acid, in low concentrations. The second fermentation to which red wines can be submitted (malolactic fermentation) is responsible for the transformation of malic acid into lactic acid (Garde-Cerdán et al., 2011). These phenomena may explain the separation of grape juices and red wines by PC1 and the separation of white wine (CHE) by PC2 (malolactic fermentation may not have occurred).

Based on the results obtained in the PCA, the applicability of this analysis as a tool to control the quality of beverages derived from grapes is evidenced and the methodology for the analysis of grape juices and wines described in this study was validated.

\section{Conclusions}

The methodology described in this paper allowed the simultaneous determination of the main organic acids and sugars in wines and grape juices by HPLC-DAD-RID, in a simple 20 -min run. The values obtained for the validation of the parameters linearity (R), precision (CV\%), recovery percentage (RC\%), detection limits (LOD) and quantification (LOQ) were considered adequate for the intended purpose. Sugars and organic acids are important for the sensory acceptance of wines and grape juices by consumers and the values obtained for these metabolites in products from northeast Brazil are in line with those mentioned in the literature for similar products from other regions around the world, demonstrating that although these samples originate from an atypical region, they show acceptable values. The profiles obtained for the sugars and acids in the samples studied were consistent with the typical features of each product, demonstrating the reliability of this methodology for the characterization of matrices such as grape juices and white, red and sparkling wines.

\section{References}

Ali, K., Maltese, F., Choi, Y.H., Verpoorte, R., 2010. Metabolic constituents of grapevine and grape-derived products. Phytochem. Rev. 9, 357-378.

Apolinar-Valiente, R., Romero-Cascales, I., Williams, P., Gómez-Plaza, E., López-Roca, J.M., Ros-García, J.M., Doco, T., 2015. Oligosaccharides of cabernet sauvignon, syrah and monastrell red wines. Food Chem. 179, 311-317.

Ball, S., 2011. Agilent hi-Plex columns for superior resolution of organic acids in wine. In: Ball, S., Bullock, S., Lloyd, L., Mapp, K., Ewen, A. (Eds.), Analysis of Carbohydrates, Alcohols, and Organic Acids by Ion-exchange Chromatography. Agilent Technologies Inc., Santa Clara, CA, USA, pp. 1-3. Available at: https://www.agilent.com/cs/ library/applications/5990-8801EN\%20Hi-Plex\%20Compendium.pdf .

Brasil, 2004. Ministério da agricultura pecuária e abastecimento. Portaria n ${ }^{\circ} 55$ De 27 De Julho De 2004, Normas Referentes à Complementação Dos Padrões De Identidade E Qualidade Do Vinho E Dos Derivados Da Uva E Do Vinho. Diário Oficial da União, Brasília 30 July 2004.

Brasil, 2011. Ministério da agricultura, pecuária e abastecimento. Guia De Validação E Controle De Qualidade Analítica: Fármacos Em Produtos Para Alimentação Animal E Medicamentos Veterinários. Secretaria de Defesa Agropecuária, Brasília. Available at: http://www.agricultura.gov.br/arq_editor/file/Laboratorio/Guia-de-validacaocontrole-de-qualidade-analitica.pdf .

Cescutti, P., Rizzo, R., 2001. Divalent cation interactions with oligogalacturonides. J. Agric. Food Chem. 49, 3262-3267.

Chinnici, F., Spinabelli, U., Riponi, C., Amati, A., 2005. Optimization of the determination of organic acids and sugars in fruit juices by ion-exclusion liquid chromatography. J. Food Compos. Anal. 18, 121-130.

Ehling, S., Cole, S., 2011. Analysis of organic acids in fruit juices by liquid chromatography-mass spectrometry: an enhanced tool for authenticity testing. J. Agric. Food 
Chem. 59, 2229-2234.

Eurachem, 2014. Eurachem Guide The Fitness for Purpose of Analytical Methods - A Laboratory Guide to Method Validation and Related Topics, (2nd ed. 2014). ISBN 978-91-87461-59-0. Available from http://www.eurachem.org .

Eyéghé-Bickong, H.A., Alexandersson, E.O., Gouws, L.M., Young, P.R., Vivier, M.A., 2012. Optimisation of an HPLC method for the simultaneous quantification of the major sugars and organic acids in grapevine berries. J. Chromatogr. B Anal. Technol. Biomed. Life Sci. 885-886, 43-49.

Eyduran, S.P., Akin, M., Ercisli, S., Eyduran, E., Maghradze, D., 2015. Sugars, organic acids, and phenolic compounds of ancient grape cultivars (Vitis Vinifera L.) from Igdir province of eastern Turkey). Turkey. Biol. Res. 48, 1-8.

Garde-Cerdán, T., Martínez-Gil, A.M., Lorenzo, C., Lara, J.F., Pardo, F., Salinas, M.R. 2011. Implications of nitrogen compounds during alcoholic fermentation from some grape varieties at different maturation stages and cultivation systems. Food Chem. 124, 106-116.

Hubaux, A., Vos, G., 1970. Decision and detection limits for linear calibration curves. Anal. Chem. 42, 849-855.

Kelebek, H., Selli, S., Canbas, A., Cabaroglu, T., 2009. HPLC determination of organic acids, sugars, phenolic compositions and antioxidant capacity of orange juice and orange wine made from a Turkish cv. Kozan. Microchem. J. 91, 187-192.

Lima, L.L.A., Schuler, A., Guerra, N.B., Pereira, G.E., Lima, T.L., Rocha, H., 2010. Otimização e validação de méodo para determinação deácidos orgânicos em vinhos por cromatografia líquida de alta eficiência. Quim. Nova 33, 1186-1189.

Lima, M.D.S., Silani, I.D.S.V., Toaldo, I.M., Corrêa, L.C., Biasoto, A.C.T., Pereira, G.E., Bordignon-Luiz, M.T., Ninow, J.L., 2014. Phenolic compounds, organic acids and antioxidant activity of grape juices produced from new Brazilian varieties planted in the Northeast Region of Brazil. Food Chem. 161, 94-103.

Lima, M.D.S., Dutra, M.D.C.P., Toaldo, I.M., Corrêa, L.C., Pereira, G.E., Oliveira, D.D., Bordignon-Luiz, M.T., Ninow, J.L., 2015. Phenolic compounds, organic acids and antioxidant activity of grape juices produced in industrial scale by different processes of maceration. Food Chem. 188, 384-392.

Lopez, E.F., Gomez, E.F., 1996. Simultaneous determination of the major organic acids, sugars, glycerol, and ethanol by HPLC in grape musts and white wines. J. Chromatogr. Sci. 34, 254-257.

Mato, I., Suárez-Luque, S., Huidobro, J.F., 2007. Simple determination of main organic acids in grape juice and wine by using capillary zone electrophoresis with direct UV detection. Food Chem. 102, 104-112.

Morvai, M., Molnár-Perl, I., 1992. Simultaneous gas chromatographic quantitation of sugars and acids in citrus fruits, pears, bananas, grapes, apples and tomatoes. Chromatographia 34, 502-504.

Muñoz-robredo, P., Robledo, P., Manríquez, D., Molina, R., 2011. Characterization of sugars and organic acids in comermercial varieties of table grape. Chil. Jar 71, 2-8.

OIV Organisation Internationale de la Vigne et du Vin. 2011. Recueil des methods internationals d'analyse des vins et des mouts, edition 2011. 8th Assemblee Generale, 21 June 2010, Paris.

Padilha, A.C.T., Biasoto, L.C., Corrêa, M.D.S., Lima, G.E., Pereira, 2016. Phenolic compounds profile and antioxidant activity of commercial tropical red wines (Vitis vinifera L.) from Sêo. Francisco Valley, Brazil. J. Food Biochem. 1-9.

Padilha, C.V.S., Miskinis, G.A., Souza, M.E.A.O., Pereira, G.E., Oliveira, D., BordignonLuiz, M.T., Lima, M.d.S., 2017. Rapid determination of flavonoids and phenolic acids in grape juices and wines by RP-HPLC/DAD: Method validation and characterization of commercial products of the new Brazilian varieties of grape. Food Chem. 228, $106-115$.

Parpinello, G.P., Rombolà, A.D., Simoni, M., Versari, A., 2015. Chemical and sensory characterisation of Sangiovese red wines: comparison between biodynamic and organic management. Food Chem. 167, 145-152.

Pereira, G.E., Padilha, C.V.S., Biasoto, A.C.T., Canuto, K.M., Nascimento, A.M., Souza, J. F., 2015, Le poids des consommateurs sur évolution des vins: exemple de la Vallée du São Francisco, Brésil. In: Pérard, J., Perrot, M. (Org.), Vin et civilisation. Les étapes de l'humanisation. 1st ed. Dijon : Centre Georges Chevrier, 2016, v. 9, 301-310.

Quijada-Morín, N., Williams, P., Rivas-Gonzalo, J.C., Doco, T., Escribano-Bailón, M.T., 2014. Polyphenolic, polysaccharide and oligosaccharide composition of Tempranillo red wines and their relationship with the perceived astringency. Food Chem. 154, 44-51.

Regmi, U., Palma, M., Barroso, C.G., 2012. Direct determination of organic acids in wine and wine-derived products by Fourier transform infrared (FT-IR) spectroscopy and chemometric techniques. Anal. Chim. Acta 732, 137-144.

Ribeiro, T.P., de Lima, M.A.C., Alves, R.E., 2012. Maturação e qualidade de uvas para suco em condições tropicais, nos primeiros ciclos de produção. Pesqui. Agropecu. Bras. 47, 1057-1065.

Rizzon, L.A., Miele, A., 2012. Analytical characteristics and discrimination of Brazilian commercial grape juice nectar, and beverage. Ciência e Tecnol. Aliment. 32, 93-97.

Saurina, J., 2010. Characterization of wines using compositional profiles and chemometrics. TrAC - Trends Anal. Chem. 29, 234-245.

Scherer, R., Rybka, A.C.P., Ballus, C.A., Meinhart, A.D., Filho, J.T., Godoy, H.T., 2012. Validation of a HPLC method for simultaneous determination of main organic acids in fruits and juices. Food Chem. 135, 150-154.

Silva, F.L.N., Schmidt, E.M., Messias, C.L., Eberlin, M.N., Frankland, Helena, Sawaya, A.C., 2015. Quantitation of organic acids in wine and grapes by direct infusion electrospray ionization mass spectrometry. Anal. Methods 7, 53-62.

Soyer, Y., Koca, N., Karadeniz, F., 2003. Organic acid profile of Turkish white grapes and grape juices. J. Food Compos. Anal. 16, 629-636.

Tang, X., Liu, J., Dong, W., Li, P., Li, L., Lin, C., Zheng, Y., Hou, J., Li, D., 2013. The cardioprotective effects of citric acid and L-malic acid on myocardial ischemia/reperfusion injury. Evid.-Based Complement. Altern. Med. 2013.

Tronchoni, J., Gamero, A., Arroyo-López, F.N., Barrio, E., Querol, A., 2009. Differences in the glucose and fructose consumption profiles in diverse Saccharomyces wine species and their hybrids during grape juice fermentation. Int. J. Food Microbiol. 134, 237-243.

Vanhatalo, E., Kulahci, M., 2015. Impact of autocorrelation on principal components and their use in statistical process control. Qual. Reliab. Eng. Int (n/a-n/a).

Ziółkowska, A., Wąsowicz, E., Jeleń, H.H., 2016. Differentiation of wines according to grape variety and geographical origin based on volatiles profiling using SPME-MS and SPME-GC/MS methods. Food Chem. 213, 714-720. 